\title{
Technology of caper (capparis spinosa) seed preparation for cultivation and cultural growth
}

\author{
I. Asatov ${ }^{1, *}, A$. Merganov ${ }^{2}$, and Z. Abdullaev ${ }^{2}$ \\ ${ }^{1}$ Tashkent State Agrarian University, University str., 2, Tashkent province, Uzbekistan, 100140 \\ ${ }^{2}$ Namangan Institute of Engineering and Technology, Kosonsoy str., 7, Namangan, Uzbekistan, \\ 160115
}

\begin{abstract}
This article discusses the importance of capers plant, its biological and, medicinal properties of the plant for human health, its chemical composition and important biological and physiological properties in preparing the seeds for planting for cultural cultivation, differences from other seeds, types of chemical stimulants and their concentrations scientific significance has been shown. There is information on planting times and planting depths, and, schemes and technologies for cultivating capers, and technologies for culturally holistic care of the cavernous plant is presented. Practical instructions are given for preparing the seed of capers for sowing, setting the planting dates, preparing the ground for planting and implementing pest control measures. The results of research in 2018-2019 in the implementation of these important technological measures are also described.
\end{abstract}

\section{Introduction}

Capers plant (Capparis spinosa) grows wild in steppe and desert regions. Although this plant has a history of 2700 years, detailed information about it was not given enough in the literature $[1,2]$. The technology of its cultivation, use and processing in the processing industry of its products has not been studied This species plant is found in the countries of Georgia and Azarbaydjon from the Commonwealth countries, in small areas France, Spain, Italy and North America, and is known from certain sources of preparation of various products from them $[3,5]$. In folk medicine, all parts of this species of plant have been used for the treatment of various diseases [1,4]. With the development of medicine and the development and use of modern techniques and chemical drugs, there was no need for such natural medicinal plants $[6,7]$.

In the regions and districts of the Republic of Uzbekistan there are lands that do not have steppes, deserts and water supply, and such lands are rarely used. The use of such areas for agriculture and increasing their economic efficiency is one of the pressing issues in agriculture, ensuring the ecological environment, purity of nature, reproduction and protection of rare plant species is a requirement of the time. One of such plants is the Capers (Capparis spinoza) plant, which is considered a drought-resistant and perennial

\footnotetext{
* Corresponding author: i.a.asatov@yandex.com
} 
plant. Its fruit is characterized by the presence in its composition of rutin, quartzetin, sugars, thiaglicosides, glycosides, iodine substance [3]. Due to this chemical property, it has been used in folk medicine for the treatment of asthma, gastrointestinal tract, hepatitis, tuberculosis, cholera, worms, goiter, ulcers and white spots on the body. However, in recent years the use of medicinal plants which grow in nature has significantly decreased $[1,8]$.

In the fauna of Uzbekistan, such medicinal plant species are endless, but they are rarely used in the preparation of medicines in the pharmaceutical industry [3].

The representatives of capers plant (Capparis spinosa) family are herbaceous and shrub plants without milk thistle. Their leaves are simple or wedge-shaped complex, located in a bandaged queue, often without lateral leaves $[4,5]$. The flowers are bisexual, solitary or in inflorescences. The calyx has 4 leaves and the petals have 4 diagonally. The paternity is unlimited, the mother has 1-2 nodes on the top, one or more cells and many seed buds. The seed bud is curved a vegetable plant that is pollinated by insects as the fruit is bent; the fruit is boll-shaped with poppy seeds or berry, cracked fruit.

\section{Materials and methods}

Proceeding from this, we have set ourselves the goal of developing the technology of seedling preparation for the cultivation of the capers plant from seeds for cultivation in a cultural way, and what changes will be in the phases of growth and development, as well as the study of the technology of its cultivation in a cultural way.

Capers plant seeds are fundamentally different from other vegetable seeds, the seeds are solid and contain up to $30 \%$ fat, which makes it very difficult to absorb water due to the presence of linoleic $\left(\mathrm{C}_{17} \mathrm{H}_{31} \mathrm{COOH}\right)$ and linolenic $\left(\mathrm{C}_{17} \mathrm{H}_{29} \mathrm{COOH}\right)$ from unsaturated carbonic acids. Therefore, the seeds of naturally growing species are stored for years until there is a moderate environment in the soil. The seeds are spread by rodents and birds, but they are spread over buildings, in steppe and desert regions in the form of undigested waste $[9,10]$.

Seeds for culturally reproducing the capers plant, including various stimulants with the help of indolyl fatty acid and indole acetic acid and naphthylacetic acid it is required to dissolve fats and saturate them with water $[5,6]$.

In order to prepare the seeds for planting, it is desirable to use different concentrations of stimulants indolyl fatty acid. A positive effect on the fertility of seeds was determined. One gram of indolyl fatty acid stimulator was taken for the study. Concentrations of 25.50 and $100 \mathrm{mg} / \mathrm{l}$ of working solutions were prepared from the maternal solution. The seeds were processed for 2-3 hours. According to the study, the germination of seeds saturated with a concentration of indolyl fatty acid stimulant $100 \mathrm{mg} / \mathrm{l}$ is $35-40$ days. The fertility rate was $85-90 \%$ (Table 1 and Figure 1). 
Table 1. Influence of indolyl fatty acid stimulator concentration on seed germination

\begin{tabular}{|c|c|c|c|c|c|}
\hline ôे & 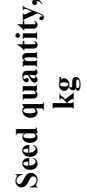 & 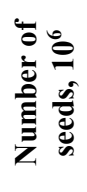 & 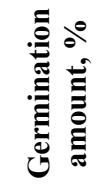 & 总 & 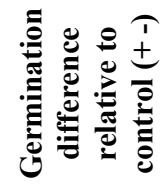 \\
\hline Water (st) & 1.0 & 50.0 & $10-15$ & $90-100$ & \\
\hline $\begin{array}{l}\text { Indolyl fatty } \\
\text { acid stimulator } \\
\text { concentration }\end{array}$ & & & & & \\
\hline $25 \mathrm{mg} / \mathrm{l}$ & 1.0 & 50.0 & $50-55$ & $60-70$ & +40 \\
\hline $50 \mathrm{mg} / \mathrm{l}$ & 1.0 & 50.0 & $60-70$ & $35-40$ & +60 \\
\hline $100 \mathrm{mg} / \mathrm{l}$ & 1.0 & 50.0 & $85-90$ & $25-30$ & +75 \\
\hline
\end{tabular}

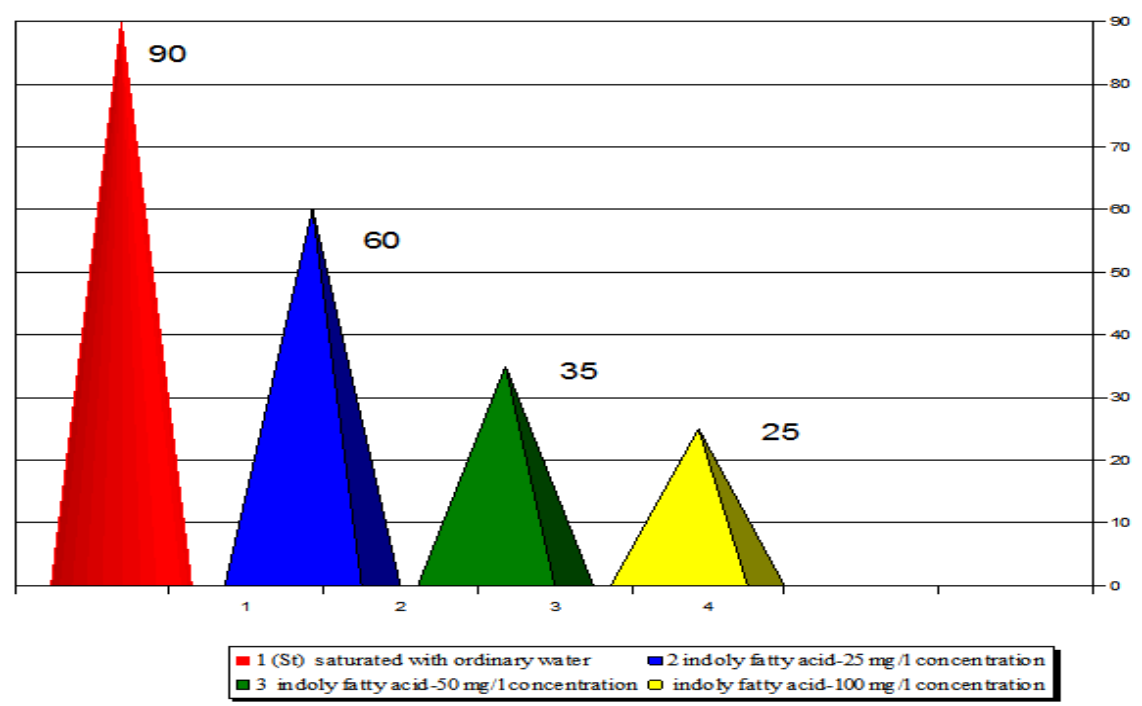

Fig. 1. Effect of indolyl fatty acid stimulator concentration on seed germination day

Before sowing the seeds of capers plant, it is important to take into account the amount of fat contained in it. In order to saturate them with water and to form full seedlings, the seeds are additionally sown in the fall to saturate the seeds indolyl fatty acid stimulant with a concentration of $100 \mathrm{mg} / \mathrm{l}$ for 2-3 days, and in early spring the seeds saturated with the stimulator in a special thermostat for 3-4 days 65-70 degrees. Striped (harvested) sowing at a temperature of gives high yields. It is recommended to spend one gram of stimulant for this [7-9] (Figure 2). 

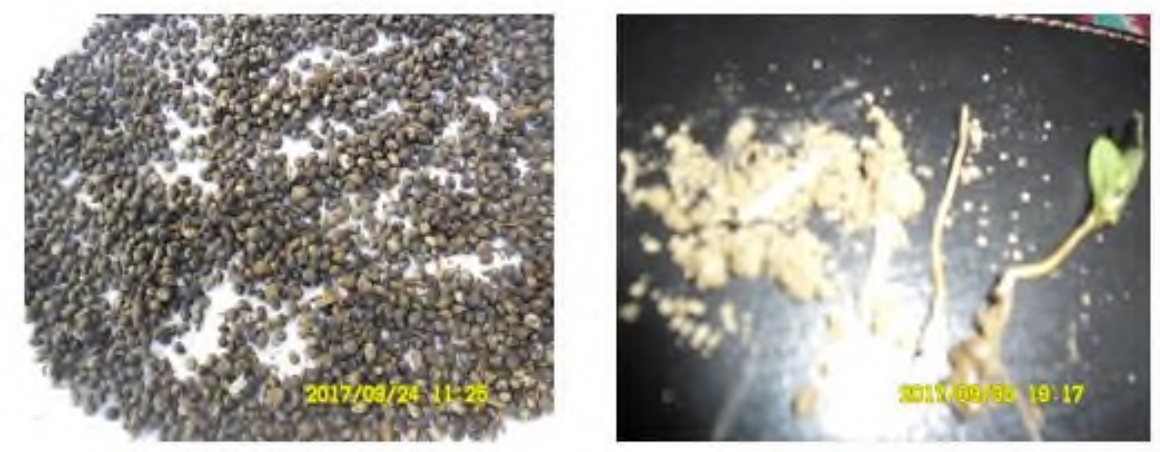

Fig. 2. Seeds processed using Indoleacetic acid (IAA) stimulator and the degree of their germination

Due to the biological and physiological characteristics of the capers plant (Capparis spinosa), it can also be grown on land that does not have a steppe and water supply. The plant naturally grows and develops well in such conditions. However, their productivity will not be high. In order to get high yields from them, it is necessary to select cultivated varieties and implement agro-technical measures, like other vegetable crops to grow them. In particular, it is advisable to prepare seeds for sowing, specify planting dates, prepare the ground for sowing and take measures to protect against pests [10].

Before sowing the seeds are separated from the rocky and low-water soils, they are obtained buds $90 \times 30$ or $100 \times 30 \mathrm{~cm}$ wide. The established intervals are dug and 50-100 grams of decomposed organic fertilizer or biohumus is added to them, and 2-3 seeds of high germination are sown in November at a depth of 2-3 cm in each nest. 800-900 grams of seeds are spent per hectare. The sown seeds germinate in March, when the air and soil temperature is $15-16{ }^{\circ} \mathrm{C}$, due to the natural humidity in autumn and spring. Seedlings germinated in March are softened and shaped into a bowl to retain moisture [11].

In the first and second years of the capers plant actively develops underground and aboveground part, the depth of the root reaches 1.5-2 meters in the second year, the aboveground part grows to 1.2-1.5 meters by the end of the vegetation. The upper part of the plant completely dries up in the late November and December and begins to grow again from March next year. After 2-3 years, they are fully developed and begin to give yield. The dynamics of productivity are varied depending on their age and environmental conditions. For this purpose, it was observed in wild-grown 4-6-year-old (control variant), experimental variants 2-3, 4-6 and 6-8-year-old plants [12].

\section{Results and discussion}

According to the results of the observation, up to 22 fruits per bush with an average weight of 26.4 tons per hectare, the weight of fruit which is an average of 10 grams were harvested in the control variant, while in a 4-6 year old cultivated plant this figure was up to 80 fruits per bush, weighing 15 grams and up to 36 tons per hectare. Compared to the remaining options, 33.36-39.36 tons were harvested. In the second variant, 9.46 tons less than in the control variant is characterized by the fact that the plant is now 2-3 years old. They have already started the ripening period. Up to 42.0 tons were harvested from 6-8 year old plants, 21.6 tons more than in the control variant (Table 2 and Figure 3). 
Table 2. Dynamics of yield of a capers plant in different ages

\begin{tabular}{|c|c|c|c|c|c|c|}
\hline 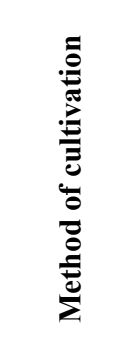 & ô & 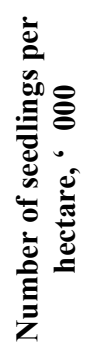 & 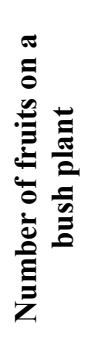 & 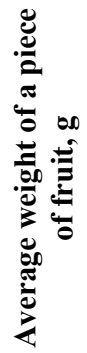 & 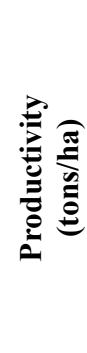 & 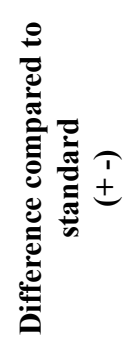 \\
\hline $\begin{array}{l}\text { Natural } \\
\text { context }\end{array}$ & $\begin{array}{c}4-6 \\
\text { years old }\end{array}$ & 12 & 22 & 10 & 2.64 & - \\
\hline \multirow{3}{*}{$\begin{array}{l}\text { Cultural } \\
\text { context }\end{array}$} & $\begin{array}{c}2-3 \\
\text { years old }\end{array}$ & 30 & 28 & 12 & 12.4 & +9.46 \\
\hline & $\begin{array}{c}4-6 \\
\text { years old }\end{array}$ & 30 & 80 & 15 & 36 & +33.36 \\
\hline & $\begin{array}{c}6-8 \\
\text { years old }\end{array}$ & 28 & 100 & 15 & 42 & +39.36 \\
\hline
\end{tabular}

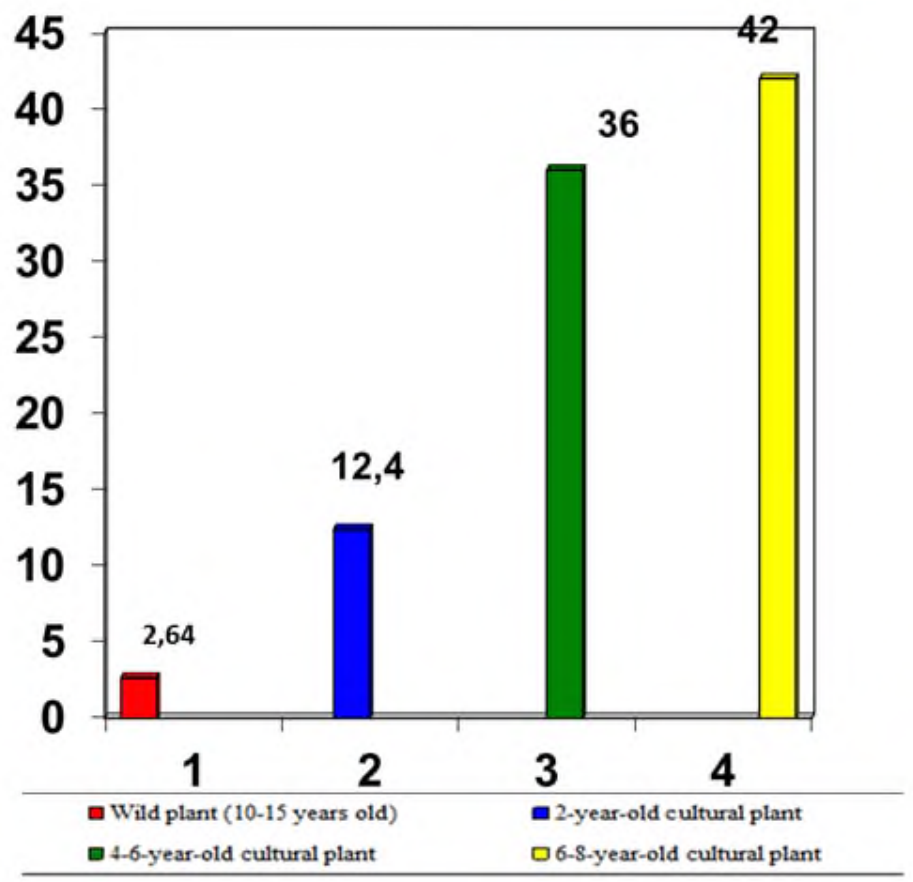

Fig. 3. Dynamics of yield of a capers plant in different ages

In the harvested areas, the preparation of seeds from the part left for the purpose of sowing seeds during the harvesting process will begin from the second decade of June. During this period, large fruits are in the phase of biological maturity, if they are not harvested on time, they open and the seeds fall to the ground (Figure 4). 

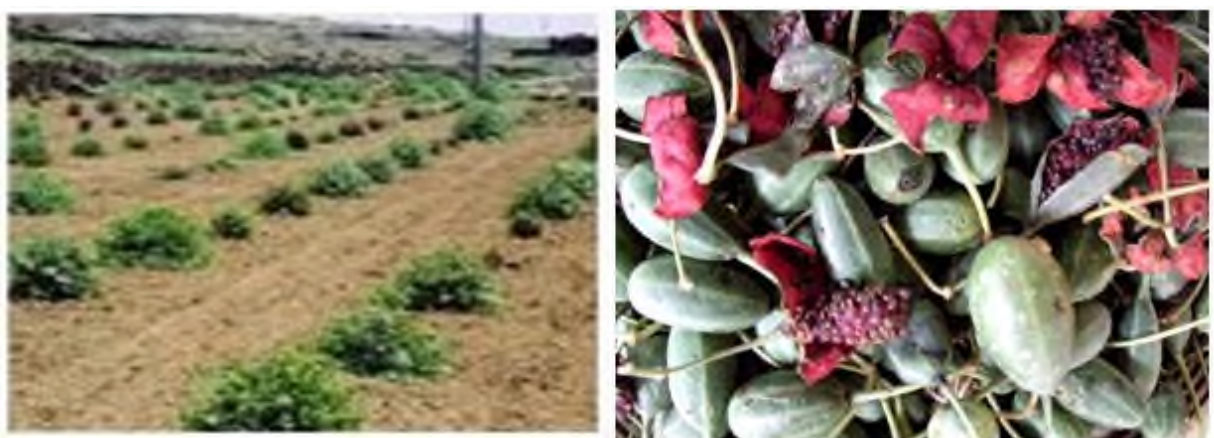

Fig. 4. Phases of biological maturity of the capers plant

During the observation period, the number of seedlings per hectare, the number of seeds in one fruit, the weight of 1000 seeds per hectare, the total amount of seeds per hectare and the quality of their condensation were determined in 4 variants, that is, the 4-6-year-old plant growing naturally (control option), in experimental variants 2-3, 4-6 and 6-8-year-old plants. (Table 3 and Figure 5)

According to the results of the observation, the number of seedlings in the control variant was 12,000 , with 150-200 seeds in per fruit, 1000 grains weighing 16 grams, 6.6 tons of seeds per hectare; the quality of the obtained seeds was $30 \%$ or 1.9 tons. Pure and quality seeds were obtained.

This indicator includes 30,000 seedlings per hectare in a cultivated plant of the same age (4-6 years old) with 650-700 seeds per hectare, with an average weight of 20 grams per 1000 seeds and 12.4 tons of seeds per hectare. The quality index was found to be $80 \%$ or 9.9 tons of the total seed obtained was conditioned seed. This figure is 8.0 tons more than the standard option (Table 3 ).

Table 3. Amount of seeds grown from a capers plant and the amount of condensation in it

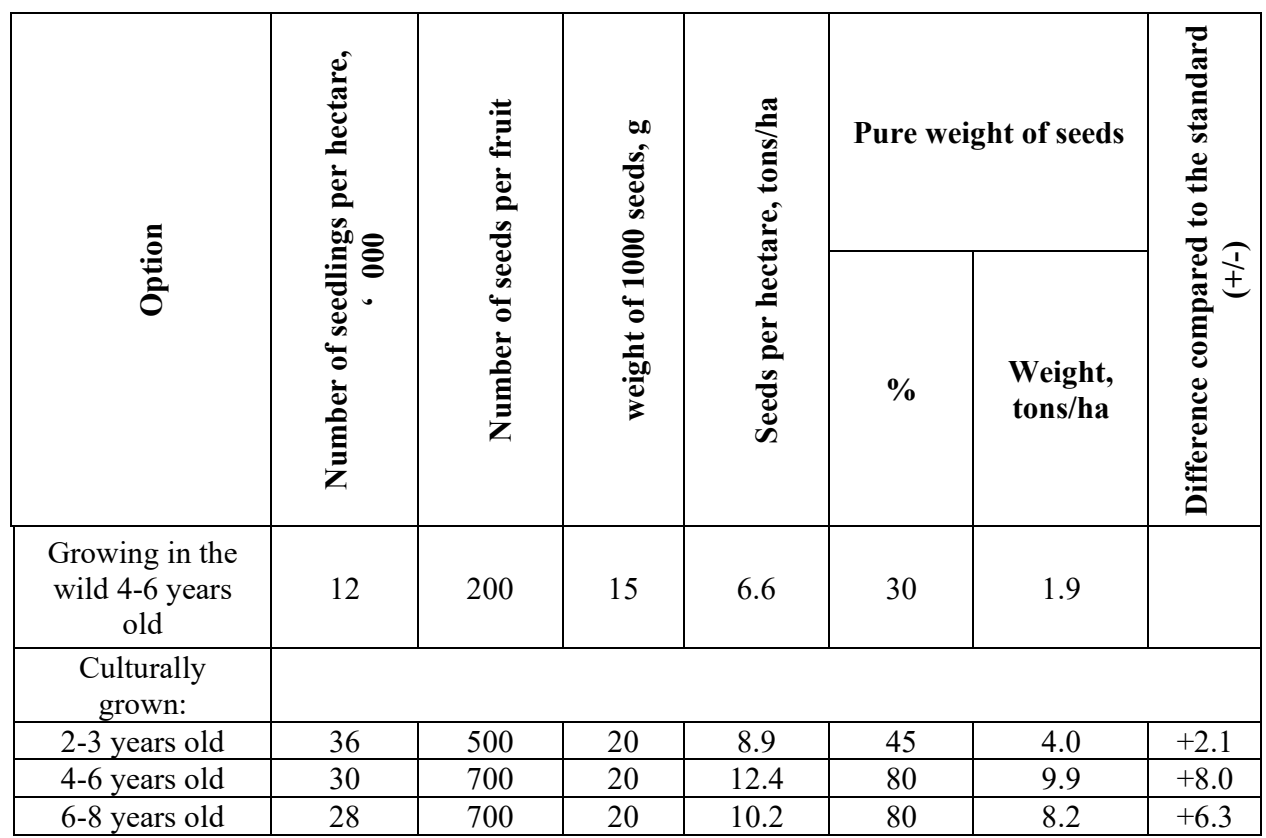




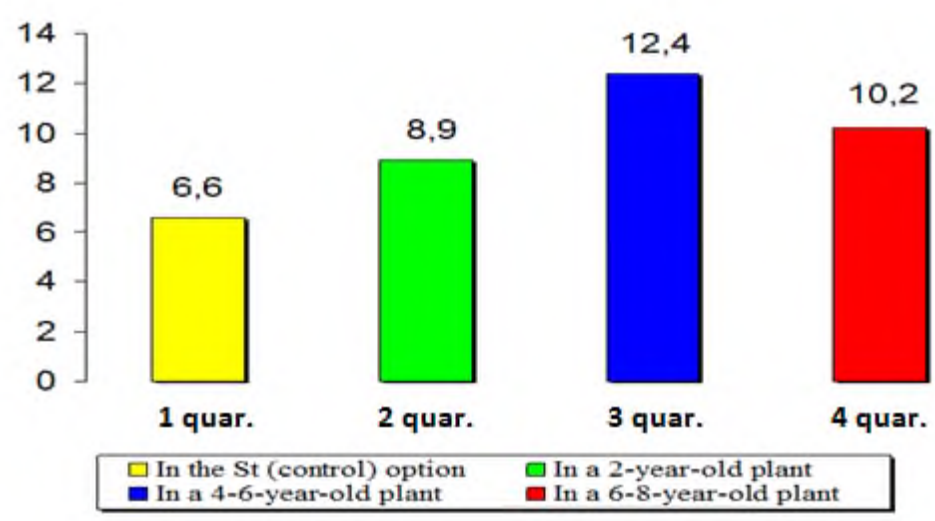

Fig. 5. Dynamics of seed yield grown from capers plant

The distinctive value of capers plant differs from other types of vegetables in that it is rich in sugar, rutin, vitamins $\mathrm{C}, \mathrm{P}$ and $\mathrm{E}$, glycosides and iodine in all parts, including fruit, and it has the ability to treat various diseases in medicine, as well as increase the resistance of the human body to various diseases. As a result of the study, it was determined that such chemicals are related to the age of the plant and the growing environment. At the same time, one of the most characteristic substances in the control variant was $0.28 \%$, and the iodine content was $19 \%$. Vitamin C -133-150 mg \% and iodine content of 25-28 mg were observed to vary (Table 4).

Table 4. Chemicals in fruits and seeds of capers plant and their quantity

\begin{tabular}{|c|c|c|c|c|c|c|}
\hline ڤే & 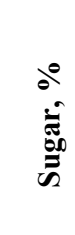 & 关 & 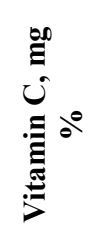 & 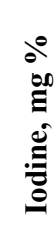 & 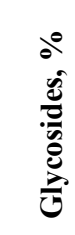 & 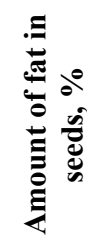 \\
\hline $\begin{array}{c}\text { Growing in the } \\
\text { wild } 4-6 \text { years } \\
\text { old }\end{array}$ & 9.2 & 0.28 & 128.0 & 19 & 28.0 & 30.0 \\
\hline $\begin{array}{l}\text { Culturally } \\
\text { growing 2-3 } \\
\text { years old }\end{array}$ & 11.3 & 0.30 & 133.0 & 25 & 28.0 & 32.0 \\
\hline 4-6 years old & 12 & 0.33 & 150.0 & 28 & 30.0 & 36.0 \\
\hline 6-8 years old & 12 & 0.32 & 150.0 & 28 & 30.0 & 36.0 \\
\hline
\end{tabular}

The analysis of the obtained results showed that the agro-techniques and technology of cultivation have a positive effect on the quality of the product, yield can be increased by 1.5-2 times, its quality indicators by $2.5-2.8$ times, and it was determined that from the ripened seeds it is possible to extract up to $30-36 \%$ oil. 


\section{Conclusion}

Based on these experiments, the following conclusions were made. Saturation of seeds for sowing of capers (Capparis sipinosa) plant with indolyl fatty acid -stimulator at a concentration of $100 \mathrm{ml} / \mathrm{l}$ for 2-3 days gives high efficiency. Before sowing the seeds are required to put in a thermostat at a temperature of $60-70{ }^{\circ} \mathrm{C}$. Due to the seeds are protected by a hard cell shell and are oily, sowing in the fall in November gives good results. Before sowing the seeds, rocky and low-water soils are separated; Sowing buds are prepared 90x30 or $100 \times 30 \mathrm{~cm}$ wide. The established intervals are dug and 50-100 grams of decomposed organic fertilizer or biohumus is added to them, and 2-3 seeds of high germination are sown in November at a depth of $2-3 \mathrm{~cm}$ in each nest. The results of the experiment showed that when the capers plant is grown culturally, it turns out that the product specificity and quality indicators can be significantly better than when grown wild.

\section{References}

1. V. Gianguzzi, P. Inglese, E. Barone, F. Sottile, Plants 8(6), 177 (2019)

2. M. R. Labbafi, A. Mehrafarin, H. N. Badi, M. Ghorbani, M. Tavakoli, Trakia Journal of Sciences 16(1), 71 (2018)

3. S. S. Murodova, R. M. Artikova, Biotechnology of Agriculture, 280 (TSAU Press, Tashkent, 2009)

4. A. Wojdyło, P. Nowicka, M. Grimalt, P. Legua, M. S. Almansa, A. Amorós, F. Hernández, Plants 8(12), 539 (2019)

5. M. R. Labbiafi, A Mehrafarin, H. Naghdi Badi, M. Ghorbani, M. Tavakoli, Journal of Sciences 16(1), 2-3 (2018)

6. V. Gianguzzi, P. Inglese, E. Barone, F. Sottile, Plants (Basel) 8(6), 5-6 (2019)

7. I. Musallam, M. Duwayri, A. Shibli, Global science book, 21-23 (2011)

8. S. Nabavi, F. Maggi, M. Daglia, S. Habtemariam, L. Rastrelli, S. Nabavi, Arch Med Res 42, 658-668 (2018)

9. S. Afsharypour, K. Jeiran, A. Jazy, Pharm Acta Helv. 72, 307-309 (1998)

10. M. Ahvazi, F. Khalighi-Sigaroodi, M. Charkhchiyan, F. Mojab, V. Mozaffarian, H. Zakeri, Iran J Pharm Res 11, 185-194 (2011)

11. M. Eddouks, A. Lemhadri, J. Michel, J. Ethnopharmacol 94, 143-148 (2004)

12. X. Feng, J. Lu, H. Xin, L. Zhang, Y. Wang, K. Tang, Plant Syst Evol 228,123-141 (2001) 